\title{
SNW Domain-Containing Protein 1
}

National Cancer Institute

\section{Source}

National Cancer Institute. SNW Domain-Containing Protein 1. NCI Thesaurus. Code C29993.

SNW domain-containing protein 1 (536 aa, $61 \mathrm{kDa}$ ) is encoded by the human SNW1 gene. This protein is involved in the regulation of both transcription and mRNA splicing. 